\title{
Bacteriohopanepolyols record stratification, nitrogen fixation and other biogeochemical perturbations in Holocene sediments of the central Baltic Sea
}

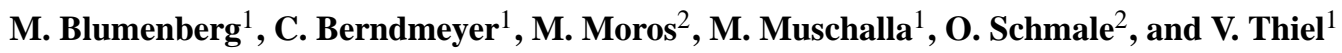 \\ ${ }^{1}$ Geobiology Group, Geoscience Centre, Georg-August-University Göttingen, Goldschmidtstr. 3, 37077 Göttingen, Germany \\ ${ }^{2}$ Leibniz Institute for Baltic Sea Research Warnemünde (IOW), Seestraße 15, 18119 Rostock, Germany \\ Correspondence to: M. Blumenberg (martin.blumenberg@geo.uni-goettingen.de)
}

Received: 28 November 2012 - Published in Biogeosciences Discuss.: 5 December 2012

Revised: 8 March 2013 - Accepted: 29 March 2013 - Published: 23 April 2013

\begin{abstract}
The Baltic Sea, one of the world's largest brackishmarine basins, established after deglaciation of Scandinavia about 17000 to $15000 \mathrm{yr}$ ago. In the changeable history of the Baltic Sea, the initial freshwater system was connected to the North Sea about $8000 \mathrm{yr}$ ago and the modern brackishmarine setting (Littorina Sea) was established. Today, a relatively stable stratification has developed in the water column of the deep basins due to salinity differences. Stratification is only occasionally interrupted by mixing events, and it controls nutrient availability and growth of specifically adapted microorganisms and algae. We studied bacteriohopanepolyols (BHPs), lipids of specific bacterial groups, in a sediment core from the central Baltic Sea (Gotland Deep) and found considerable differences between the distinct stages of the Baltic Sea's history. Some individual BHP structures indicate contributions from as yet unknown redoxcline-specific bacteria (bacteriohopanetetrol isomer), methanotrophic bacteria (35-aminobacteriohopanetetrol), cyanobacteria (bacteriohopanetetrol cyclitol ether isomer) and from soil bacteria (adenosylhopane) through allochthonous input after the Littorina transgression, whereas the origin of other BHPs in the core has still to be identified. Notably high BHP abundances were observed in the deposits of the brackish-marine Littorina phase, particularly in laminated sediment layers. Because these sediments record periods of stable water column stratification, bacteria specifically adapted to these conditions may account for the high portions of BHPs. An additional and/or accompanying source may be nitrogen-fixing (cyano)bacteria, which is indicated by a positive correlation of BHP abundances with $\mathrm{C}_{\mathrm{org}}$ and $\delta^{15} \mathrm{~N}$.
\end{abstract}

\section{Introduction}

The Baltic Sea had a variable geological and biogeochemical history after it originated $17000-15000 \mathrm{yr}$ before present (BP; see comprehensive summary in Andrén et al., 2011). After deglaciation of Scandinavia, the closed basin of the modern Baltic Sea was filled with melt water and a freshwater system developed around $16000 \mathrm{yr} \mathrm{BP}$, the so-called Baltic Ice Lake. This oligotrophic lake setting was terminated about $11700 \mathrm{yr}$ BP by a pulse of marine water that entered the Baltic Sea via a passage through south-central Sweden and led to a slightly brackish environment (Yoldia Sea). Freshwater conditions re-established about $10700 \mathrm{yr}$ BP (Ancylus Lake), until the major marine transgression took place via the Kattegat, resulting in the establishment of the modern Littorina Sea. The onset of the Littorina Sea stage is still a matter of discussion (see e.g. Rößler et al., 2011). Dating based on calcareous fossils revealed 8100-8000 yr BP in the Great Belt (e.g. Bennike et al., 2004) and Mecklenburg Bight (Rößler et al., 2011), and $7200 \mathrm{yr}$ BP in Arkona Basin (e.g. Moros et al., 2002). Bulk sediment dates revealed older ages of 8500-8000 yr BP for the onset in Bornholm Basin (Andrén et al., 2000a) and Gotland Basin (Andrén et al., 2000b).

The ingression of marine North Sea waters led to the development of a stratified water body in the deep basins of the central Baltic Sea, with more saline, denser waters in the lower water column. Such conditions also characterise one of the deepest basins of the modern Baltic Sea - the Gotland Deep ( $249 \mathrm{~m}$ water depth). In this basin there exists a relatively stable oxic-anoxic transition zone (redoxcline) 
at about $100 \mathrm{~m}$ water depth. The stratification of the Gotland Deep is only occasionally disturbed by turbulent vertical transport processes and inflows of North Sea water (Reissmann et al., 2009). The stratification has major consequences on the nutrient situation of the central Baltic Sea and the composition of pelagic micro- and macroorganisms (e.g. Labrenz et al., 2007; Schmale et al., 2012). For instance, high nutrient input with excess phosphorus loads promotes growth of nitrogen-fixing cyanobacteria (Nausch et al., 2009; Wasmund et al., 2012).

Numerous micropalaeontological and biogeochemical studies on the Holocene in the central Baltic Sea exist, mainly reflecting the change from oligotrophic freshwater conditions (Ancylus Lake) to a brackish-marine setting (Littorina Sea) with widespread deep water anoxia (e.g. Sohlenius et al., 1996; Bianchi et al., 2000; Brenner, 2001, 2005; Voss et al., 2001). As a result of the Littorina Sea transgression, marine diatoms and dinoflagellates entered the central Baltic Sea (Brenner, 2005), and cyanobacteria became increasingly important as indicated by pigment and molybdenum abundances (Bianchi et al., 2000; Kunzendorf et al., 2001; Poutanen and Nikkila, 2001; Borgendahl and Westman, 2007). Due to the lack of preservable cell remnants, however, information about the microbial protagonists of biogeochemical cycling in the changeful history of the central Baltic Sea is scarce. An organic geochemical approach was made by Nytoft and Larsen (2001), who reported changes in the composition of bacterial hopanoid hydrocarbons from the Gotland Deep and concluded that bacteria became more prominent during the Littorina Sea stage. Our study aims to specify these bacterial contributions to the Holocene sediments of the Gotland Deep by using one of the most ubiquitous classes of lipids, bacteriohopanepolyols (BHPs). BHPs are produced by many groups of bacteria and are excellently suitable for palaeoreconstructions of contributions from metabolically and phylogenetically distinct bacteria into lake and marine sediments (e.g. Talbot and Farrimond, 2007; Coolen et al., 2008; Blumenberg et al., 2009; Taylor and Harvey, 2011). So far, only one report of BHPs from surface sediments of the central Baltic Sea exists (Berndmeyer et al., 2013). This study focused on BHPs from methanotrophic bacteria living in the redoxcline of the Gotland Deep water column and clearly demonstrated the utility of BHPs to reflect water column processes. The current study is aimed at BHPs and selected other biomarkers in deeper Holocene sediments of the Gotland Deep. Our goal is to bridge the gap between the relatively well known record of eukaryotic remains and the much less understood bacteria and, by that, to get a better understanding of bacterial primary production and redoxcline-related processes in the geological history of the central Baltic Sea.

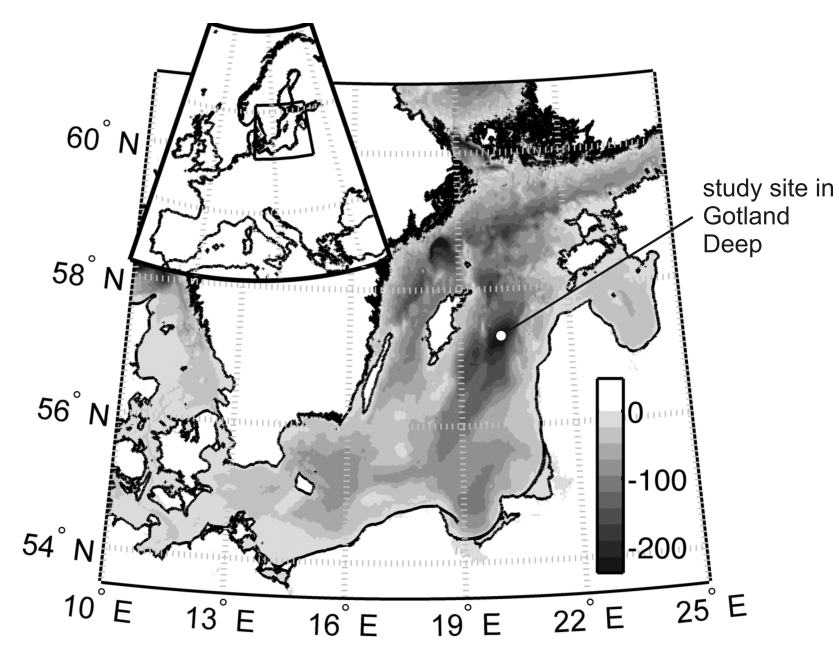

Fig. 1. Study site (station 52-07) in the central Baltic Sea.

\section{Study site and core stratigraphy}

During a research cruise with RV Maria S. Merian in summer 2010, an $11.6 \mathrm{~m}$ long gravity core, together with a "Frahmlot" core to obtain undisturbed surface layers, were taken in the Gotland Deep (240 m water depth; station MSM 161 52-07; coordinates: $57^{\circ} 16.998$; E $20.7182^{\circ}$; for sampling site see Fig. 1). The cores cover sedimentary depositions of all stages of the Baltic Sea's history. Sediment depths in the figures are composites resulting from lithostratigraphic correlation of the gravity and the Frahmlot corer. The deposits of the Baltic Ice Lake were characterised by brownish and clayish sediments with low visible organic matter content ( $\sim 1000$ to $680 \mathrm{~cm}$ below sea floor (cmbsf); Fig. 2). Similarly organic-lean Ancylus Lake sediments were found between 680 to $\sim 440 \mathrm{cmbsf}$. A black colour in the upper Ancyclus Lake layer is most likely due to precipitation of sulphide bands after downward diffusion of $\mathrm{H}_{2} \mathrm{~S}$ from sulfate reduction in the overlying Littorina Sea deposits (Boesen and Postma, 1988; Sohlenius et al., 1996; Moros et al., 2002). The brackish-marine Littorina Sea sediments start at $440 \mathrm{cmbsf}$ and partially show fine lamination, characterising times of pronounced and stable deep water anoxia. Strongly laminated sediments between 60 and $90 \mathrm{cmbsf}$ and in the uppermost $20 \mathrm{cmbsf}$ most likely represent deposits of the warm stages Medieval Climate Anomaly (MCA, from AD 950 to 1250 ) and the Modern Warm Period (MoWP, since $\sim \mathrm{AD}$ 1850 ), respectively, while the organic-lean sediments in between record the Little Ice Age (LIA, from $\sim$ AD 1350 to 1850; ages inferred from Kabel et al., 2012). 


\section{Material and methods}

\subsection{Sample preparation and bulk analyses $\left(\mathrm{C}_{\text {org }}, \mathrm{N}\right.$, $\left.\delta^{15} \mathrm{~N}, \mathrm{LOI}\right)$}

The core was stored cool on board and in the laboratory until sampling in February 2011 (samples for biomarker and bulk analyses were then stored frozen until further analyses). The upper three samples were obtained from the accompanying Frahmlot (MSM 16-1 52-04) and data were taken from Berndmeyer et al. (2013). The samples were homogenised by grinding, and aliquots were taken for elemental analyses (C/N/S) using a Eurovector Euro EA CNS analyser. To determine the contents of organic carbon $\left(\mathrm{C}_{\mathrm{org}}\right)$, each sample was also analysed after decarbonatisation with $\mathrm{HCl}$. The error for $\mathrm{C}$ and $\mathrm{N}$ analyses are generally $<2$ and $5 \%$, respectively. Bulk $\delta^{15} \mathrm{~N}$ isotope analysis was carried out in duplicate using elemental analysis-isotope ratio mass spectrometry (EA-IRMS, Delta plus, Thermo scientific). The lab standard deviation of this method is $0.1 \%$. The loss on ignition (LOI) was determined in high resolution for the upper $500 \mathrm{~cm}$ of the gravity core by ashing freeze-dried samples at $550^{\circ} \mathrm{C}(3 \mathrm{~h})$ and calculating the resulting mass difference (wt.\%).

\subsection{Extraction, column chromatography and derivatisation}

About $7.5 \mathrm{~g}$ of the sediments was extracted three times $(20 \mathrm{~min})$ with $40 \mathrm{ml}$ of a mixture of dichloromethane $(\mathrm{DCM})$ and methanol $(\mathrm{MeOH})(3: 1, \mathrm{v} / \mathrm{v})$ in a CEM Mars 5 microwave (Matthews, NC, USA) at $80^{\circ} \mathrm{C}$ and $800 \mathrm{~W}$. An aliquot of the combined extract was acetylated and analysed for bacteriohopanepolyols by liquid chromatographymass spectrometry (LC-MS; see below). Acetylation was performed using a mixture of acetic acid anhydride and pyridine $\left(1: 1, \mathrm{v} / \mathrm{v}, 50^{\circ} \mathrm{C}\right.$ for $1 \mathrm{~h}$ and overnight at room temperature). The pyridine/acetic acid anhydride mixture was then dried under vacuum. Another aliquot was separated by column chromatography into a hydrocarbon (F1), a ketone and alcohol (F2), and a polar fraction (F3; details are described in Blumenberg et al., 2009). Resulting alcohols in the F2 were silylated using BSTFA (N,Obis[trimethylsilyl]trifluoroacetamide) for $1.5 \mathrm{~h}$ at $80^{\circ} \mathrm{C}$.

\subsection{Gas chromatography-mass spectrometry (GC-MS)}

The hydrocarbon and alcohol fractions (F1 and F2) were analysed using GC-MS (Varian CP-3800 chromatograph coupled to a $1200 \mathrm{~L}$ mass spectrometer), and peaks were identified by comparing mass spectra and retention times with published data. The system was equipped with a fused silica column (Phenomenex Zebron ZB-5MS, $30 \mathrm{~m}, 0.25 \mu \mathrm{m}$ film thickness, i.d. $0.32 \mathrm{~mm}$ ). Helium was used as carrier gas and the temperature programme was $80^{\circ} \mathrm{C}(3 \mathrm{~min})$ to $310^{\circ} \mathrm{C}$ at $4{ }^{\circ} \mathrm{C} \mathrm{min}^{-1}$ (held $25 \mathrm{~min}$ ).

\subsection{Liquid chromatography-mass spectrometry (LC-MS)}

Details about LC-MS analyses and quantification of bacteriohopanepolyols (BHPs) can be found elsewhere (Blumenberg et al., 2010). Briefly, LC-MS was performed using a Prostar Dynamax High-Performance Liquid Chromatography (HPLC) system interfaced with a 1200L triple quadrupole mass spectrometer (both Varian). HPLC separation was achieved using a Merck Lichrocart (Lichrosphere 100; RPC18e $5 \mu \mathrm{m}$ column; $250 \times 4 \mathrm{~mm}$ ) and a Merck Lichrosphere pre-column of the same material. Quantifications were done using external standards of BHPs, bacteriohopanetetrol and 35-aminobacteriohopanetriol, with known concentrations. Routine replicate analyses of the standard BHPs revealed an error in quantification of $\pm 20 \%$.

\section{Results}

\subsection{Bulk geochemical data and stratigraphy}

$\mathrm{C}_{\text {org }}$ as well as high-resolution LOI data are presented in Fig. 2. In the central Baltic Sea, LOI (\%) approximately mirrors $\mathrm{C}_{\text {org }}(\%)$, if divided by 2.5 (Leipe et al., 2010), and this conversion factor appears to be also valid for the studied core from the Gotland Deep (see converted LOI data in Fig. 2). The high resolution of LOI data allowed a comparison with dated cores from the same area (Lougheed et al., 2012; see supplementary figure). Four maxima in $\mathrm{C}_{\text {org }}$ were found, the lower of which represents the establishment of the Littorina Sea (about $440 \mathrm{cmbsf}$; peak at $420 \mathrm{cmbsf} \sim 6500 \mathrm{yr}$ $\mathrm{BP}$ ), the peak at $290 \mathrm{cmbsf}$ represents $4500 \mathrm{yr} \mathrm{BP}$, and the peak at $70 \mathrm{cmbsf}$ that of the MCA (maximising at $\sim 800 \mathrm{yr}$ $\mathrm{BP})$. The uppermost $\mathrm{C}_{\text {org }}$ maximum records the MoWP of the last $100 \mathrm{yr}\left(\mathrm{C}_{\text {org }}\right.$ data from Frahmlot $)$.

In Fig. 3, $\mathrm{C}_{\text {org }}$ is compared with $\delta^{15} \mathrm{~N}$ and $\mathrm{C} / \mathrm{N}$ ratios. As clearly demonstrated in Fig. $3 \mathrm{~b}, \mathrm{C}_{\mathrm{org}}$ and $\delta^{15} \mathrm{~N}$ are excellently negatively correlated ( $p$ value $3 \times 10^{-7}$; excluding the surface samples). Lowest $\mathrm{C} / \mathrm{N}$ ratios of about 5 were observed during the Baltic Ice Lake and Ancylus Lake stages and highest $\mathrm{C} / \mathrm{N}$ values of about 10 in sediments deposited during the Littorina stage. The maximum value of 12.9 was observed in the deepest sediment sample of the Littorina Sea stage.

\subsection{Biomarkers}

Figure 4 shows concentrations of selected biomarkers in the Gotland Deep sediments. Highest abundances of nonacosane $\left(n \mathrm{C}_{29}\right)$ were found in Baltic Ice Lake and Ancylus Lake samples ( $~ 600$ to $1000 \mathrm{cmbsf}$; up to $150 \mu \mathrm{g} \mathrm{g}^{-1} \mathrm{C}_{\text {org }}$, Fig. 4a). All core samples revealed a high carbon preference index (CPI) of $>5$, reflecting a strong odd-over-even carbon number predominance and thus a mostly terrestrial origin of $n \mathrm{C}_{29}$ and other long-chain $n$-alkanes (Bray and 


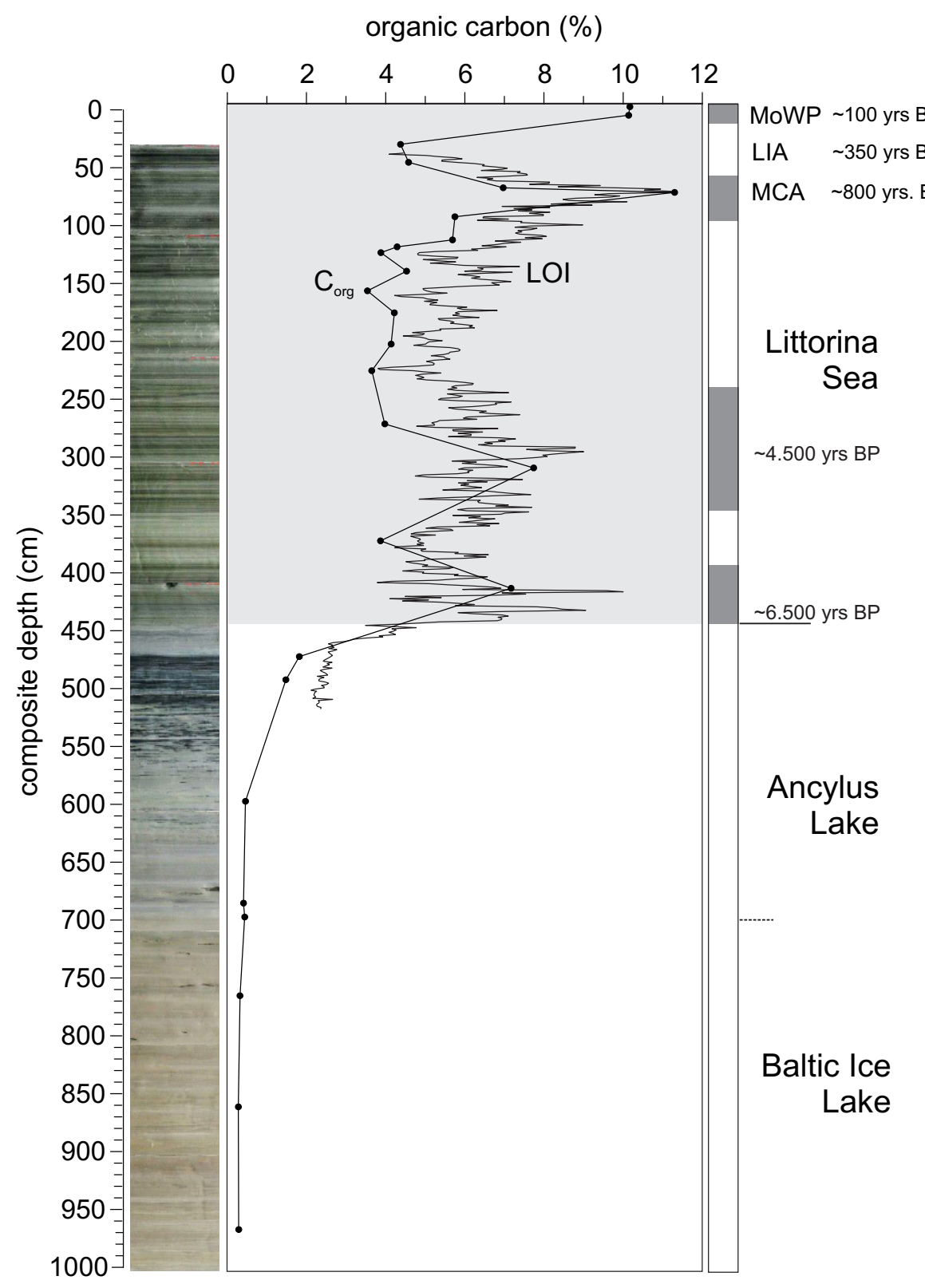

Fig. 2. $\mathrm{C}_{\text {org }}$ concentrations of the samples used for biomarker analyses in comparison with LOI (loss on ignition) data obtained at higher resolution. Dark grey areas in the column on the right represent sediments with strong lamination and thus pronounced and stable water column stratification during the Littorina Sea stage. Layers in between lacked strong bottom water anoxia, at least for extended periods of time. Ages are inferred from correlations with the master core described in Lougheed et al. (2012). In the central Baltic Sea, LOI have to be divided by approximately 2.5 to obtain $\mathrm{C}_{\text {org }}$ abundances (Leipe et al., 2010). LIA = Little Ice Age; MCA = Medieval Climate Anomaly, MoWP $=$ Modern Warm Period.

Evans, 1961). Above the Ancylus Lake-Littorina Sea transition, concentrations clearly decreased to about $20 \mu \mathrm{g} \mathrm{g}^{-1}$ $\mathrm{C}_{\text {org }}$. In the Littorina Sea sediments, concentrations of $n \mathrm{C}_{29}$ were relatively stable, demonstrating low fluctuations of terrestrial plant input. In contrast to $n \mathrm{C}_{29}$, abundances of dinosterol ( $4 \alpha, 23,24$-trimethyl-5 $\alpha$-cholest-22E-en-3 $\beta$-ol), a 4methyl steroid prominent in dinoflagellates (Withers, 1983), is positively correlated with total $\mathrm{C}_{\text {org }}$ (Fig. 4b).
Similar to dinosterol, the sum of bacteriohopanepolyols (BHPs) revealed highest abundances in the Littorina Sea sediments. Within this lithological unit, particularly high BHP amounts, maximising at about $600 \mu \mathrm{g} \mathrm{g}^{-1} \mathrm{C}_{\text {org }}$, were observed in the most organic-rich layers. Whereas dinosterol increased at the establishment of the Littorina Sea stage, BHPs had already risen during the late Ancylus Lake stage (after the initial Littorina transgression at about $470 \mathrm{cmbsf}$ ). The 


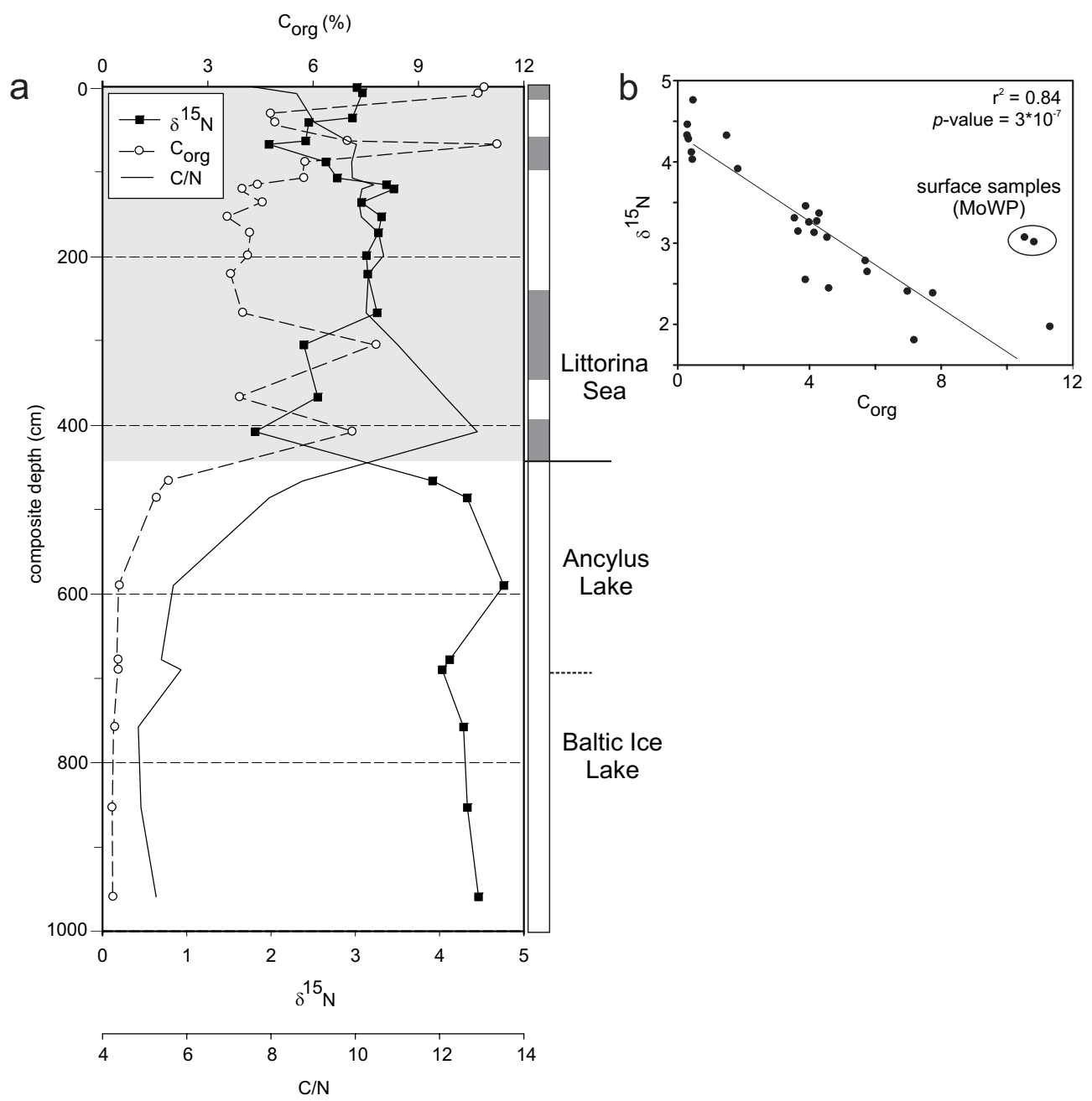

Fig. 3. (a) Concentrations and distributions of bulk geochemical data $\left(\mathrm{C}_{\mathrm{org}}, \delta^{15} \mathrm{~N}\right.$, and $\left.\mathrm{C} / \mathrm{N}\right)$. Shaded areas in dark grey mark strongly laminated Littorina Sea sediment layers (see caption of Fig. 2). (b) Cross plot of $\mathrm{C}_{\mathrm{org}}$ with $\delta^{15} \mathrm{~N}$. Surface samples were excluded from the correlation. MoWP = Modern Warm Period.

lowest BHP concentrations were observed in the earlier Ancylus Lake and Baltic Ice Lake sediments. The Gotland Deep core contains eight distinct BHPs whose individual distributions are shown in Fig. 5. Highest amounts were found for bacteriohopanetetrol (BHT) and 32,35-anhydroBHT, with the latter showing greater abundances with increasing depth. 35 -aminobacteriohopanetriol and -tetrol were prominent in sediments representing the beginning of the Littorina Sea stage. BHT cyclitol ethers (two isomers; tentatively identified by co-elutions with previously identified BHT cyclitol isomers) were first observed in sediments of the late Ancylus Lake stage and were omnipresent, although in low abundance, in the sediments of the Littorina Sea. In the lowermost Littorina Sea stage sample studied (at $420 \mathrm{cmbsf}$ ), an unknown BHT isomer was found, whose elution characteristics correspond with a BHT isomer found in the recent Gotland Deep water column (Berndmeyer et al., 2013).

\section{Discussion}

\subsection{Biogeochemical changes in the Holocene as reflected by bulk geochemical parameters}

The sediments from the Gotland Deep markedly reflect the establishment of the marine-brackish Littorina Sea in a steep increase in $\mathrm{C}_{\text {org }}$, probably due to enhanced preservation and/or increasing primary production, and the deposition of strongly laminated sediments (Fig. 2; see discussion below). A peak in $\mathrm{C}_{\text {org }}$ was also observed at about $800 \mathrm{yr} \mathrm{BP}$, most likely reflecting high organic carbon accumulation and sediment lamination during the MCA. The sediments deposited during the subsequent cooler period (Little Ice Age; LIA) are characterised by low $\mathrm{C}_{\text {org }}$ and most likely oxic conditions in the bottom waters (Sohlenius et al., 1996; Andrén et al., 2000b; Fig. 2). Above, the MoWP and recent anthropogenic influence are reflected by a parallel increase in $\delta^{15} \mathrm{~N}$ and $\mathrm{C}_{\text {org }}$ 

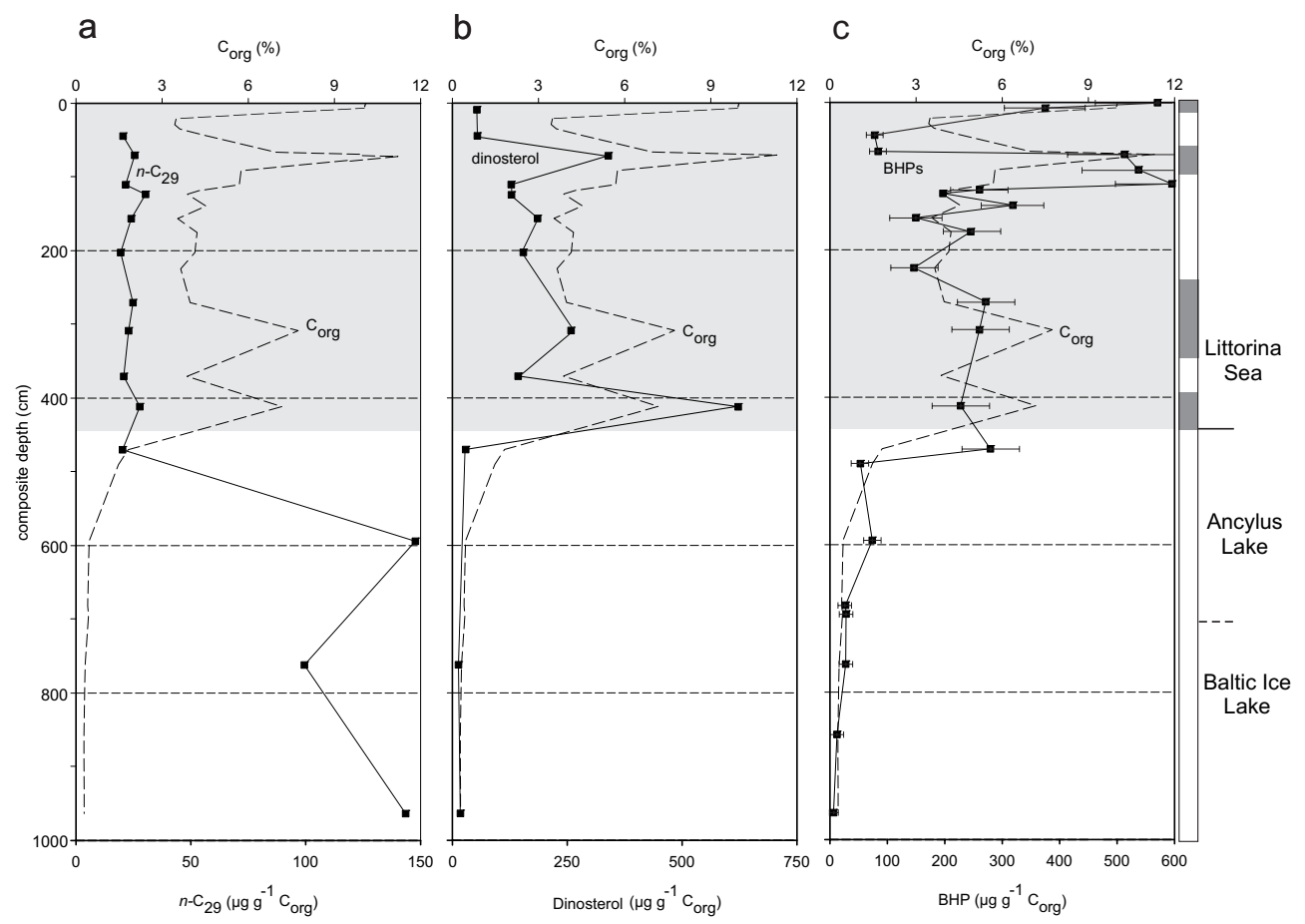

Fig. 4. Selected biomarkers in the Holocene sediments of the Gotland Deep in comparison with $\mathrm{C}_{\text {org. }}$ (a) Nonacosane $\left(n \mathrm{C}_{29}\right)$, representing higher plant inputs; (b) dinosterol ( $4 \alpha, 23,24$-trimethyl-5 $\alpha$-cholest-22E-en-3 $\beta$-ol), representing dinoflagellate inputs; (c) total BHP, representing inputs from hopanoid-producing bacteria. Error bars show the analytical uncertainty of BHP analyses of $20 \%$. Shaded areas in dark grey mark strongly laminated Littorina Sea sediment layers. BHP concentrations for the surface sediment samples $(0-2$ and 6-8 cmbsf) were taken from Berndmeyer et al. (2013).

(Voss et al., 2001; Struck et al., 2000). Except for the samples from the MoWP, $\mathrm{C}_{\text {org }}$ correlates negatively with bulk $\delta^{15} \mathrm{~N}$ (Fig. 3). Enhanced growth of cyanobacteria capable of biological nitrogen fixation is a plausible explanation for low $\delta^{15} \mathrm{~N}$ values, a scenario which has been suggested for numerous settings (Sachs and Repeta, 1999; Kuypers et al., 2004; Blumenberg et al., 2009), including the Baltic Sea (Bianchi et al., 2000; Voss et al., 2001; Voss, 2005). The increasing importance of nitrogen fixing cyanobacteria after the Littorina Sea transgression is demonstrated by enhanced occurrences of cyanobacterial carotenoid pigments and molybdenum, which is an essential micronutrient to facilitate nitrogen fixation (Poutanen and Nikkila, 2001; Kunzendorf et al., 2001; Borgendahl et al., 2007). Today, cyanobacteria contribute about $45 \%$ to the bulk sedimentary nitrogen (Struck et al., 2004). Flourishing of nitrogen-fixing (cyano)bacteria is commonly promoted by phosphorus excess (lowering N/P ratios) through riverine input or release from anoxic sediments (Bianchi et al., 2000). Consequently, the establishment of a stratified, partly anoxic water body after the Littorina Sea transgression is a conceivable scenario for a decrease of $\mathrm{N} / \mathrm{P}$ ratios and an increase in cyanobacterial biomass. A further reduction in the N/P ratio may have been induced by bacterial denitrification under the established anoxic conditions (Haug et al., 1998; Struck et al., 2000). Due to the high energy costs of cleaving $\mathrm{N}_{2}$, nitrogen-fixing cyanobacteria have only an advantage over algae in waters depleted in bioavailable nitrogen (Karl et al., 2002). Hence, the good correlation between high $\mathrm{C}_{\text {org }}$ and low $\delta^{15} \mathrm{~N}$ argues for (i) a major role of nitrogen-fixing (cyano)bacteria during the deposition of organic-rich, laminated sediments (e.g. after the Littorina Sea transgression, and during the MCA), and for (ii) enhanced primary production under $\mathrm{N} / \mathrm{P}$ ratios lower than the Redfield Ratio (C/N/P: 106/16/1; (Redfield et al., 1963)). At the same time, cyanobacteria are known for biomass $\mathrm{C} / \mathrm{N}$ ratios higher than that obtained from the Redfield Ratio $(\mathrm{C} / \mathrm{N}=6.6)$. For Nodularia spumigena, an important (nitrogen-fixing) cyanobacterium in the central Baltic Sea, a C/N of 8.5 was reported (Sörensson and Sahlsten, 1987). Consequently, the observed increase in $\mathrm{C} / \mathrm{N}$ in laminated sediments after the Littorina Transgression (Fig. 3a) is well explainable with an increasing importance of cyanobacteria among the primary-producing community. Moreover, a direct temperature dependence of cyanobacterial blooming in the central Baltic Sea has also currently been reported (Kabel et al., 2012), in addition to the indirect role of high temperatures for water column stratification, and the related shift to low $\mathrm{N} / \mathrm{P}$ ratios. 

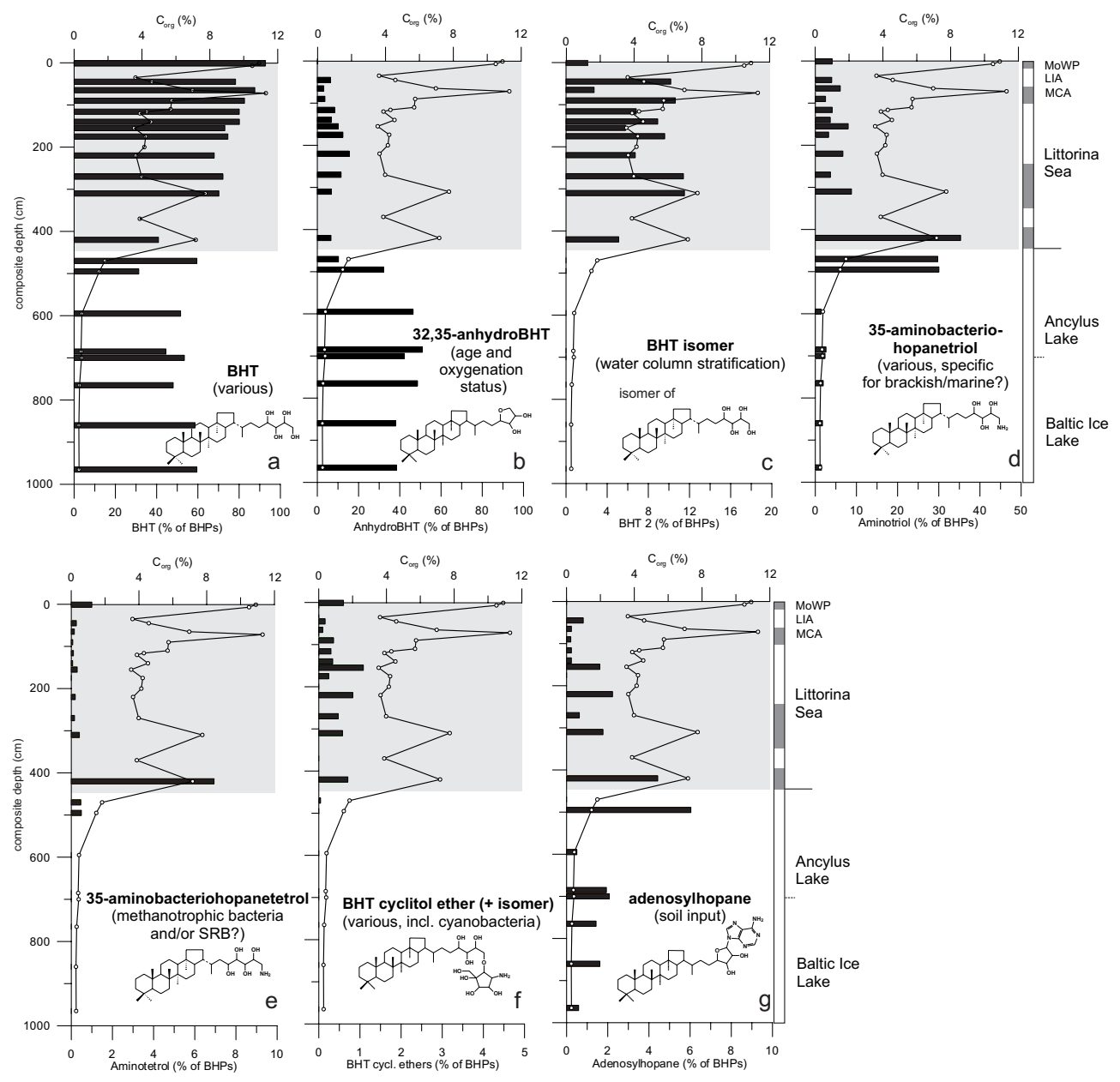

Fig. 5. Distributions of major BHPs. Note different y-axes for individual BHPs; MoWP= Modern Warm Period; LIA=Little Ice Age; $\mathrm{MCA}=$ Medieval Climate Anomaly. Shaded areas in dark grey mark strongly laminated Littorina Sea sediment layers.

\subsection{Biomarker records of biogeochemical perturbations in the central Baltic Sea}

\subsubsection{Baltic Ice Lake-Ancylus Lake transition (10700 - 9800 yr BP)}

The resolution of samples from these intervals was low, but among the studied biomarkers the transition is not reflected in any changes.

\subsubsection{Ancylus Lake-Littorina Sea transition $(\sim 8500-8000$ yr BP $)$}

In Ancylus Lake sediments, nonacosane $\left(n \mathrm{C}_{29}\right)$ was much higher in relative abundance than in Littorina Sea deposits (Fig. 4a). $n \mathrm{C}_{29}$ is a biomarker for higher plant waxes (Eglinton et al., 1962), and the concentration in the lower core demonstrates the high relevance of allochthonous input during the Ancylus Lake stage. This is supported by previous findings of abundant plant-derived triterpane biomarkers in Ancylus Lake sediments (Nytoft and Larsen, 2001).
After the Littorina Sea transgression, a substantial environmental change is reflected by a drop in $n \mathrm{C}_{29}$ abundance by an order of magnitude (Fig. 4a). At the same time, a biomarker for dinoflagellates, dinosterol (Withers, 1983), increased (Fig. 4b). Together, both biomarkers mirror the shift from an oligotrophic, terrestrially influenced system towards a setting controlled by particular brackish-marine primary producers, which fits well with micropalaeontological studies (e.g. Brenner, 2001). It must be noted, however, that dinosterol contributions in the Gotland Deep sediments appear to be largely due to marine dinoflagellates of the Littorina Sea stage, whereas the high relevance of specific freshwater dinoflagellates (e.g. Gonyaulax apiculata) reported for the Ancylus Lake stage (Brenner, 2001; Yu and Berglund, 2007) is not reflected by this biomarker.

As a result of the Littorina Sea transgression, concentrations of BHPs increased by almost two orders of magnitude and followed a similar trend to $\mathrm{C}_{\text {org }}$ (Fig. 4c). The maximum BHP concentrations of up to $600 \mu \mathrm{g} \mathrm{g}^{-1} \mathrm{C}_{\text {org }}$ were extraordinarily high compared to other marine settings (e.g. four 
times higher than in Black Sea sediments; Blumenberg et al., 2009). Similarly, diploptene, a hopanoid hydrocarbon that is produced by many bacteria along with BHP, was reported to be most abundant in the Littorina Sea stage in Gotland Deep sediments (Nytoft and Larsen, 2001). The consistently low amounts of adenosylhopane, a BHP abundant in soil bacteria (Talbot and Farrimond, 2007; Cooke et al., 2008; Fig. 5g), argues against variations in land-derived allochthonous BHP contributions as a major control on BHP patterns. Likewise, the peak in adenosylhopane in the late Ancylus Lake stage may be due to enhanced input of soil organic matter during the flooding of land areas during the Littorina transgression (Fig. 5g).

The observed trends might be also influenced, or amplified, by enhanced lipid preservation as result of the establishment of anoxic bottom waters and sediments. Enhanced preservation is crucial for high BHP abundances in sediments as these polyfunctionalised lipid structures are prone to microbial degradation. A change in the redox environment in the course of the Littorina Sea transgression is reflected in a decrease in the relative abundance of 32,35-anhydroBHT (Fig. 5b). 32,35-anhydroBHT is a diagenetic degradation product of BHT and composite BHPs under acidic and marine sedimentary conditions (Bednarczyk et al., 2005; Schaeffer et al., 2008, 2010). Higher concentrations of this diagenetic product consequently suggest a lower preservation potential in Ancylus Lake and older sediments. In turn, the generally low amounts of 32,35-anhydroBHT in Littorina Sea deposits, with lowest abundances recorded in the organicrich laminated sediments, may reflect a different preservational status of BHP. Apart from that, however, it is unlikely that total BHP concentrations, including the diagenetic product 32,35-anhydroBHT, are controlled by redox changes in bottom waters and sediments. Studies from comparable settings demonstrated a stability of BHPs up to an age of 100000 yr (Cooke et al., 2008; Coolen et al., 2008; Blumenberg et al., 2009, 2010). Providing additional evidence for production of BHPs as key control for BHP abundances in the studied core, $\mathrm{C}_{\text {org }}$ trends were found to be slightly delayed to BHPs (e.g. Ancylus-Littorina transition or at the MCA; Fig. 4). This rather indicates BHPs to record pioneer organisms of these changes.

BHPs specific for cyanobacteria were not found in the Gotland Deep sediments. However, an isomer of the common BHT cyclitol ether was observed that was also observed in the oxic part of the water column (Berndmeyer et al., 2013), which suggests a bacterial source from within the euphotic zone (Fig. 5f; BHT cyclitol ether were summed up as similar trend suggest the same origin). An isomer of the common BHT cyclitol ether was also reported from the cyanobacterium Anacystis montana (Herrmann et al., 1996), which has, however, not been reported from the recent Baltic Sea water column. The contribution of cyanobacteria to the sedimentary BHP pool in Gotland Deep sediments therefore remains ambiguous and seemingly reflects the fact that neither all cyanobacteria produce BHPs nor that their BHP inventory, if present, must always be specific.

\subsubsection{Biogeochemical variations during the Littorina Sea stage as reflected by BHPs}

Despite the generally higher importance of BHP producing bacteria in the Littorina Sea stage, internal variations in this unit were also observed. 35-aminobacteriohopanetriol is, along with BHT, a ubiquitous BHP and is produced by diverse bacterial groups. Bacteria rich in 35aminobacteriohopanetriol flourished particularly during the transition from the Ancylus Lake to the Littorina Sea where concentrations are about 4-fold higher than in all other samples studied (Fig. 5d). Which group of bacteria particularly sourced 35-aminobacteriohopanetriol is unclear, but the same maximum, at the time of the Littorina Sea transgression is revealed by a more specific BHP, 35aminobacteriohopanetetrol (Fig. 5e), which was also particularly abundant in Black Sea sediments reflecting the marine ingression after the last deglaciation (Blumenberg et al., 2009). 35-aminobacteriohopanetetrol was reported from cultured methanotrophic bacteria (Neunlist and Rohmer, 1985; Talbot et al., 2001) as well as from sulfate reducing bacteria (Blumenberg et al., 2006, 2012). Indeed, both bacterial groups can plausibly explain the observed trend in these individual BHP concentrations. First, the inflow of marine sulfate-rich waters during the Littorina Sea transgression, and the establishment of a stratified water column has likely strongly stimulated the activity of sulfate reducing bacteria in the upper sediments and bottom waters. Increased microbial sulfate reduction is also expressed by an increase in pyrite sulfur in the respective core section (data not shown; see also black pyrite layers from downward-diffusing $\mathrm{H}_{2} \mathrm{~S}$ in the uppermost Ancylus Lake sediments; Fig. 2). However, during the Littorina stage, SRB should have remained a stable part of the microbial community. This conflicts with the observed decreases in 35-aminobacteriohopanetriol and -tetrol abundances after the Littorina optimum (Fig. 5d and e). Moreover, a quantitative estimate on sedimentary SRB in a comparable sedimentary setting (the Black Sea), clearly argued against these bacteria as considerable contributor to the BHP pool in this setting (Blumenberg et al., 2009). Another possible source for both BHPs are methanotrophic bacteria, which were reported as important members of the microbial community at the recent redoxcline of the Gotland Deep water column (Schmale et al., 2012; Berndmeyer et al., 2013). Unfortunately, the analyses of $\delta^{13} \mathrm{C}$ values to characterise the bacterial source (Hayes, 1993) and particularly to identify methanotrophy (Freeman et al., 1990) were not possible for the Gotland Deep due to low concentrations. Despite this, we propose that both 35 -aminobacteriohopanetriol and -tetrol are related to pioneer methanotrophic bacteria related to the establishment of the pelagic redoxcline. 
Redoxcline processes are also reflected by another abundant BHP in Gotland Deep sediments. In the upper part of the core, we found relatively high amounts of a BHT isomer (Fig. 5c). The nature of the isomerisation was not further identified, but a BHT isomer was observed to be abundant in suboxic zones of stratified marine water columns (Sáenz et al., 2011) and near the redoxcline of a microbial mat (Blumenberg et al., 2013), and a compound with the same spectral and chromatographic properties was also reported from the redoxcline of the modern Gotland Deep water column (Berndmeyer et al., 2013). We therefore suggest that the consistent occurrence of the BHT isomer in the underlying sediments of the Littorina Sea stage records water column stratification. It appears, however, that the concentrations of this compound cannot directly be translated into the stability of the stratification because neither the strongly laminated sediments of the MCA and MoWP warm periods (intense stratification) nor the sediments of the LIA (less pronounced stratification; Zillén and Conley, 2010) show corresponding excursions in the relative abundance of the BHT isomer (Fig. 5c). Further studies are needed to corroborate the relationship of BHT isomer occurrences to redoxcline processes, as well as the identification of the biological source(s).

Apart from the ups and downs of individual BHP sources, it can be stated that the overall input of hopanoids is linked to changes in the nutrient situation (low N/P ratios with high phosphorus loads; Bianchi et al., 2000) and the establishment of water column stratification. A similar scenario may explain BHP increases in Black Sea sediments as a result of the ingression of Mediterranean waters through the Bosporus after the Last Glacial Maximum (Blumenberg et al., 2009). The correlation between the occurrence of laminated sediments, bulk $\delta^{15} \mathrm{~N}$ and total BHPs may be taken as support for a similar relationship for the Baltic Sea (Fig. 6), but may also be linked to the development of redoxclines and the establishment of redoxcline-specific BHP producing bacteria (Wakeham et al., 2007; Sáenz et al., 2011; Berndmeyer et al., 2013; Blumenberg et al., 2013). For the Gotland Deep sediments it is likely that both bacterial primary production under low $\mathrm{N} / \mathrm{P}$ ratios and the presence of a redoxcline controlled BHP abundances, but which factor prevailed is unclear. Nevertheless, the stability of the stratification is most likely an important factor as BHP abundances appear to be exceedingly high during warmer times (e.g. during the MCA and the MoWP). Future studies should focus on the identification of microbial BHP producers thriving at these biogeochemical zones because these zones appear to be key environments for the biosynthesis of the precursors of geohopanoids, which are ubiquitous in rocks, oils and sediments.

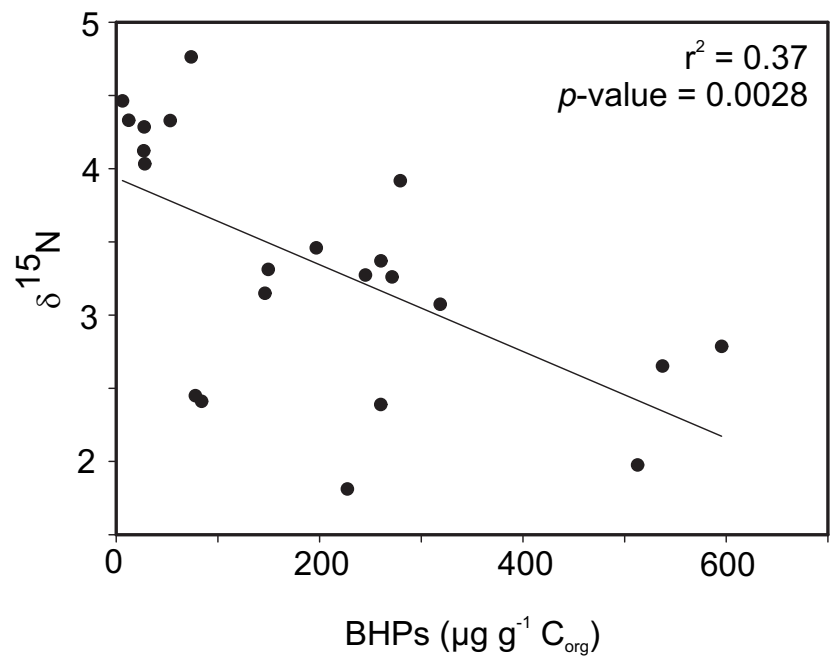

Fig. 6. Cross plot of BHP abundances with bulk $\delta^{15} \mathrm{~N}$.

\section{Conclusions}

A composite core (gravity core and Frahmlot) covering the last $9000 \mathrm{yr}$ of the central Baltic Sea history was studied for bulk geochemical parameters and selected biomarkers, with a particular focus on bacteriohopanepolyols (BHPs). Biomarker distributions and abundances in the Baltic Ice Lake (before $11700 \mathrm{yr}$ BP) and Ancylus Lake (10700 to $8500 \mathrm{yr}$ BP) sediments were similar and reflect pronounced higher plant inputs and low primary productivity. Marine dinoflagellates, as indicated by dinosterol, and BHP producing bacteria began to flourish after the Littorina Sea transgression 8500 to $8000 \mathrm{yr}$ BP. In the Littorina Sea stage, BHP concentrations are the highest so far reported from a marine or brackish setting. BHPs are most abundant in laminated sediments, pointing at an important role of hopanoidproducing bacteria during times of water column stratification and pronounced anoxia of the lower water column. Such conditions characterised, for instance, the onset of the Littorina Sea transgression, the MCA and the MoWP. Whereas the discrete microorganisms that sourced the BHPs in Gotland Deep sediments still have to be identified, the structures and distributions of individual BHPs point at contributions from methanotrophic and other bacteria specific to redoxclines, as well as most likely cyanobacteria. A good correlation between BHPs, $\mathrm{C}_{\text {org }}$ and $\delta^{15} \mathrm{~N}$ highlights an involvement of BHP-producing bacteria in the fixation of atmospheric nitrogen and, as this process is crucial for the present day Baltic Sea, underpins their role for the entire nutrient cycle in this marginal marine basin.

Acknowledgements. We thank the officer and crew of RV Merian (MSM 16-1) for excellent collaboration during field work. T. Leipe, R. Endler, and H. Arz (all IOW) are acknowledged for helpful discussion. Two anonymous reviewers are thanked for 
their helpful comments. We thank J. Dyckmans (Centre for Stable Isotope Research and Analysis, University of Göttingen) for help with stable nitrogen isotope analysis. C. Conradt (University of Göttingen) is kindly acknowledged for laboratory assistance. The study was supported by the Deutsche Forschungsgemeinschaft (DFG) through projects BL 971/1-3 and BL 971/3-1.

This Open Access Publication is funded

by the University of Göttingen.

Edited by: N. Ohkouchi

\section{References}

Andrén, E., Andrén, T., and Sohlenius, G.: The Holocene history of the southwestern Baltic Sea as reflected in a sediment core from the Bornholm Basin, Boreas, 29, 233-250, 2000a.

Andrén, E., Andrén, T., and Kunzendorf, H.: Holocene history of the Baltic Sea as a background for assessing records of human impact in the sediments of the Gotland Basin, The Holocene, 10, 687-702, 2000b.

Andrén, T., Björck, S., Andrén, E., Conley, D., Zillén, L., and Anjar, J.: Late Quaternary climate variations reflected in Baltic Sea sediments, in: The Baltic Sea Basin, edited by: Harff, J., Björck, S., Hoth, P., Springer, 449 pp., 75-97, 2011.

Bednarczyk, A., Carillo Hernandez, T., Schaeffer, P., Adam, P., Talbot, H. M., Farrimond, P., Riboulleau, A., Largeau, C., Derenne, S., Rohmer, M., and Albrecht, P.: 32,35Anhydrobacteriohopanetetrol: an unusual bacteriohopanepolyol widespread in recent and past environments, Org. Geoch., 36, 673-677, 2005.

Bennike, O., Jensen, J. B., Lemke, W., Kuijpers, A., and Lomholt, S.: Late- and postglacial history of the Great Belt, Denmark, Boreas, 33, 18-33, 2004.

Berndmeyer, C., Thiel, V., Schmale, O., and Blumenberg, M.: Biomarkers for aerobic methanotrophy in the water column of the stratified Gotland Deep (Baltic Sea). Org. Geochem., 55, 103-111, 2013.

Bianchi, T. S., Engelhaupt, E., Westman, P., Andrén, T., Rolff, C., and Ragnar, E.: Cyanobacterial blooms in the Baltic Sea: Natural or human-induced?, Limnol. Oceanogr., 45, 716-726, 2000.

Blumenberg, M., Krüger, M., Nauhaus, K., Talbot, H. M., Oppermann, B., Seifert, R., Pape, T., and Michaelis, W.: Biosynthesis of hopanoids by sulfate-reducing bacteria (genus Desulfovibrio), Environ. Microbiol., 8, 1220-1227, 2006.

Blumenberg, M., Seifert, R., Kasten, S., Bahlmann, E., and Michaelis, W.: Euphotic zone bacterioplankton sources major sedimentary bacteriohopanepolyols in the Holocene Black Sea, Geochim. Cosmochim. Acta, 73, 750-766, 2009.

Blumenberg, M., Mollenhauer, G., Zabel, M., Reimer, A., and Thiel, V.: Decoupling of bio- and geohopanoids in sediments of the Benguela Upwelling System (BUS), Org. Geochem., 41, 1119-1129, 2010.

Blumenberg, M., Hoppert, M., Krüger, M., Dreier, A., and Thiel, V.: Novel findings on hopanoid occurrences among sulfate reducing bacteria: is there a direct link to nitrogen fixation?, Org. Geochem. 49, 1-5, 2012.

Blumenberg, M., Arp, G., Reitner, J., Schneider, D., Daniel, R., and Thiel, V.: Bacteriohopanepolyols in a stratified cyanobacterial mat from Kiritimati (Christmas Island, Kiribati), Org. Geochem., 55, 55-62, 2013.

Boesen, C. and Postma, D.: Pyrite formation in anoxic environments of the Baltic, Am. J. Sci., 288, 575-603, 1988.

Borgendahl, J. and Westman, P.: Cyanobacteria as a trigger for increased primary productivity during sapropel formation in the Baltic Sea-a study of the Ancylus/Littorina transition, J. Paleolimnol., 38, 1-12, 2007.

Bray, E. E. and Evans, E. D.: Distribution of n-paraffins as a clue to recognition of source beds, Geochim. Cosmochim. Acta, 22, 2-15, 1961.

Brenner, W. W.: Organic-walled microfossils from the central Baltic Sea, indicators of environmental change and base for ecostratigraphic correlation, Baltica, 14, 40-51, 2001.

Brenner, W.: Holocene environmental history of the Gotland Basin (Baltic Sea) - a micropalaeontological model, Palaeogeogr. Palaeoclimatol. Palaeoecol., 220, 227-241, 2005.

Cooke, M. P., Talbot, H. M., and Wagner, T.: Tracking soil organic carbon transport to continental margin sediments using soil-specific hopanoid biomarkers: a case study from the Congo fan (ODP site 1075), Org. Geochem., 39, 965-971, 2008.

Coolen, M. J. L., Talbot, H. M., Abbas, B. A., Ward, C., Schouten, S., Volkman, J. K., and Damste, J. S. S.: Sources for sedimentary bacteriohopanepolyols as revealed by $16 \mathrm{~S}$ rDNA stratigraphy, Environ. Microbiol., 10, 1783-1803, 2008.

Eglinton, G., Hamilton, R. J., Raphael, R. A., and Gonzales, A. G.: Hydrocarbon constituents of the wax coatings of plant leaves: A taxonomic study, Nature, 193, 739-742, 1962.

Freeman, K. H., Hayes, J. M., Trendel, J.-M., and Albrecht, P.: Evidence from carbon isotope measurements for diverse origins of sedimentary hydrocarbons, Nature, 343, 254-256, 1990.

Haug, G. H., Pedersen, T. F., Sigman, D. M., Calvert, S. E., Nielsen, B., and Peterson, L. C.: Glacial/interglacial variations in production and nitrogen fixation in the Cariaco Basin during the last 580 kyr, Paleoceanogr., 13, 427, doi:10.1029/98PA01976, 1998.

Hayes, J. M.: Factors controlling ${ }^{13} \mathrm{C}$ contents of sedimentary organic compounds: Principles and evidence, Mar. Geol., 113, 115-125, 1993.

Herrmann, D., Bisseret, P., Connan, J., and Rohmer, M.: Relative configurations of carbapseudopentose moieties of hopanoids of the bacterium Zymomonas mobilis and the cyanobacterium "Anacystis montana”, Tetrahedr. Lett., 37, 1791-1794, 1996.

Kabel, K., Moros, M., Porsche, C., Neumann, T., Adolphi, F., Andersen, T. J., Siegel, H., Gerth, M., Leipe, T., Jansen, E., and Sinninghe Damsté, J. S.: Impact of climate change on the Baltic Sea ecosystem over the past 1000 years, Nature Clim. Ch., 2, 871-847, 2012.

Karl, D., Michaels, A., Bergman, B., Capone, D., Carpenter, E., Letelier, R., Lipschultz, F., Paerl, H., Sigman, D., and Stal, L.: Dinitrogen fixation in the world's oceans, Biogeochem., 57/58, 47-98, 2002.

Kunzendorf, H., Voss, M., Brenner, W., Andrén, T., and Vallius, H.: Molybdenum in sediments of the central Baltic Sea as an indicator for algal blooms, Baltica, 14, 123-130, 2001.

Kuypers, M.M.M., van Breugel, Y., Schouten, S., Erba, E., Sinninghe Damsté, J.S.: $\mathrm{N}_{2}$-fixing cyanobacteria supplied nutrient $\mathrm{N}$ for Cretaceous oceanic anoxic events, Geology, 32, 853-856, 2004. 
Labrenz, M., Jost, G., and Jürgens, K.: Distribution and abundant prokaryotic organisms in the water column of the central Baltic Sea with an oxic-anoxic interface, Aquat. Microb. Ecol., 46, 177-190, 2007

Leipe, T., Tauber, F., Vallius, H., Virtasalo, J., Uścinowicz, S., Kowalski, N., Hille, S., Lindgren, S., and Myllyvirta, T.: Particulate organic carbon (POC) in surface sediments of the Baltic Sea, Geo-Mar. Lett., 31, 175-188, 2010.

Lougheed, B.C., Snowball, I., Moros, M., Kabel, K., Muschelera, R., Virtasalo, J. J., and Wacker, L.: Using an independent geochronology based on palaeomagnetic secular variation (PSV) and atmospheric $\mathrm{Pb}$ deposition to date Baltic Sea sediments and infer ${ }^{14} \mathrm{C}$ reservoir age, Quatern. Sci. Rev., 42, 43-58, 2012.

Moros, M., Lemke, W., Kuijpers, A., Endler, R., Jensen, J. B., Bennike, O., and Gingele, F.: Regressions and transgressions of the Baltic basin reflected by a new high-resolution deglacial and postglacial lithostratigraphy for Arkona Basin sediments (western Baltic Sea), Boreas 31, 151-162, 2002.

Nausch, M., Nausch, G., Lass, H. U., Mohrholz, V., Nagel, K., Siegel, H., and Wasmund, N.: Phosphorus input by upwelling in the eastern Gotland Basin (Baltic Sea) in summer and its effects on filamentous cyanobacteria, Estuar. Coast. Shelf Sci., 83, 434-442, 2009.

Neunlist, S., Rohmer, M.: Novel hopanoids from the methylotrophic bacteria Methylococcus capsulatus and Methylomonas methanica, Biochem. J., 231, 635-639, 1985.

Nytoft, H. P. and Larsen, B.: Triterpenoids and other organic compounds as markers of depositional conditions in the Baltic Sea deep basins during the Holocene, Baltica, 14, 95-107, 2001.

Poutanen, E.-L. and Nikkila, K.: Carotenoid Pigments as Tracers of Cyanobacterial Blooms in Recent and Postglacial Sediments of the Baltic Sea, Ambio, 30, 179-183, 2001.

Redfield, A. C., Ketchum, B. H., and Richards, F. A.: The influence of organisms on the composition of sea-water, in: The Sea 2. Interscience, edited by: Hill, N., New York, 26-77, 1963.

Reissmann, J. H., Burchard, H., Feistel, R., Hagen, E., Lass, H. U., Mohrholz, V., Nausch, G., Umlauf, L., and Wieczorek, G.: Vertical mixing in the Baltic Sea and consequences for eutrophication - A review, Progr. Oceanogr., 82, 47-80, 2009.

Rößler, D., Moros, M., and Lemke, W.: The Littorina transgression in the southwestern Baltic Sea: new insights based on proxy methods and radiocarbon dating of sediment cores, Boreas, 40, 231-241, 2011.

Sachs, J. P. and Repeta, D. J.: Oligotrophy and Nitrogen Fixation During Eastern Mediterranean Sapropel Events, Science, 286, 2485-2488, 1999.

Sáenz, J. P., Wakeham, S. G., Eglinton, T. I., and Summons, R. E.: New constraints on the provenance of hopanoids in the marine geologic record: Bacteriohopanepolyols in marine suboxic and anoxic environments, Org. Geochem., 42, 1351-1362, 2011.

Schaeffer, P., Schmitt, G., Adam, P., and Rohmer, M.: Acidcatalyzed formation of 32,35-anhydrobacteriohopanetetrol from bacteriohopanetetrol, Org. Geochem., 39, 1479-1482, 2008.

Schaeffer, P., Schmitt, G., Adam, P., and Rohmer, M.: Abiotic formation of 32,35-anhydrobacteriohopanetetrol: A geomimetic approach, Org. Geochem., 41, 1005-1008, 2010.

Schmale, O., Schneider von Deimling, J., , Gülzow, W., Nausch, G., Waniek, J. J., and Rehder, G.: Distribution of methane in the water column of the Baltic Sea, Geophys. Res. Lett., 37, L12604,
doi:10.1029/2010GL043115, 2010.

Schmale, O., Blumenberg, M., Kießlich, K., Jakobs, G., Berndmeyer, C., Labrenz, M., Thiel, V., and Rehder, G.: Aerobic methanotrophy within the pelagic redox-zone of the Gotland Deep (central Baltic Sea), Biogeosciences, 9, 4969-4977, doi:10.5194/bg-9-4969-2012, 2012.

Sohlenius, G., Sternbeck, J., Andrén, E., and Westman, P.: Holocene history of the Baltic Sea as recorded in a sediment core from the Gotland Deep, Mar. Geol., 134, 183-201, 1996.

Sörensson, F. and Sahlsten, E.: Nitrogen dynamics of a cyanobacteria bloom in the Baltic Sea: new versus regenerated production, Mar. Ecol. Progr. Ser., 37, 277-284, 1987.

Struck, U., Emeis, K. C., Voss, M., Christiansen, C., and Kunzendorf, H.: Records of southern and central Baltic Sea eutrophication in $\delta^{13} \mathrm{C}$ and $\delta^{15} \mathrm{~N}$ of sedimentary organic matter, Mar. Geol., 164, 157-171, 2000.

Struck, U., Pollehne, F., Bauerfeind, E., and v. Bodungen, B.: Sources of nitrogen for the vertical particle flux in the Gotland Sea (Baltic Proper) - results from sediment trap studies, J. Mar. Syst., 45, 91-101, 2004.

Talbot, H. M. and Farrimond, P.: Bacterial populations recorded in diverse sedimentary biohopanoid distributions, Org. Geochem., 38, 1212-1225, 2007.

Talbot, M., Watson, D. F., Murrell, J. C., Carter, J. F., and Farrimond, P.: Analysis of intact bacteriohopanepolyols from methanotrophic bacteria by reversed-phase high-performance liquid chromatography-atmopheric pressure chemical ionisation mass spectrometry, J. Chromat. A, 921, 175-185, 2001.

Taylor, K. A. and Harvey, R. H.: Bacterial hopanoids as tracers of organic carbon sources and processing across the western Arctic continental shelf, Org. Geochem., 42, 487-497, 2011.

Voss, M.: Nitrogen cycle of the Baltic Sea from an isotopic perspective, Global Biogeochem. Cy., 19, GB3001, doi:10.1029/2004GB002338, 2005.

Voss, M., Kowalewska, G., and Brenner, W.: Microfossil and biogeochemical indicators of environmental changes in the Gotland Deep during the last 10000 years, Baltica, 14, 131-140, 2001.

Wakeham, S. G., Amann, R., Freeman, K. H., Hopmans, E. C., Joergensen, B. B., Putnam, I. F., Schouten, S., Sinninghe Damsté, J. S., Talbot, H. M., and Woebken, D.: Microbial eoclogy of the stratified water column of the Black Sea as revealed by a comprehensive biomarker study, Org. Geochem., 38, 2070-2097, 2007.

Wasmund, N., Nausch, G., and Voss, M.: Upwelling events may cause cyanobacteria blooms in the Baltic Sea, J. Mar. Syst., 90, 67-76, 2012.

Withers, N.: Dinoflagellates sterols, in: Marine Natural Products, edited by: Scheuer, P. J., Chemical and Biological Perspectives, Academic Press, New York, 87-130, 1983.

Yu, S.-Y. and Berglund, B. E.: A dinoflagellate cyst record of Holocene climate and hydrological changes along the southeastern Swedish Baltic coast, Quatern. Res., 67, 215-224, 2007.

Zillén, L. and Conley, D. J.: Hypoxia and cyanobacteria blooms are they really natural features of the late Holocene history of the Baltic Sea?, Biogeosciences, 7, 2567-2580, doi:10.5194/bg7-2567-2010, 2010. 